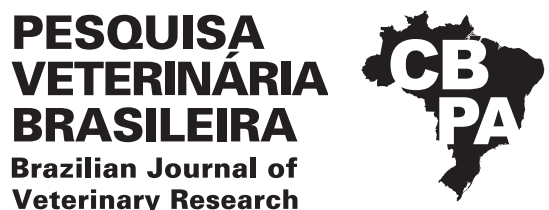

\title{
Spontaneous poisoning by Ateleia glazioviana (leg. Papilionoideae) in sheep and goats in the West region of Santa Catarina ${ }^{1}$
}

\author{
Aldo Gava ${ }^{2 *}$ (D), Franciéli A. Molossi ${ }^{2}$ (D) Daiane Ogliari $^{2}$ (D), Elaine Melchioretto² (D), \\ Eduardo Pasquali ${ }^{3}$ and José Roso ${ }^{4}$
}

\begin{abstract}
Gava A., Molossi F.A., Ogliari D., Melchioretto E., Pasquali E. \& Roso J. 2021. Spontaneous poisoning by Ateleia glazioviana (leg. Papilionoideae) in sheep and goats in the West region of Santa Catarina. Pesquisa Veterinária Brasileira 41:e06724, 2021. Laboratório de Patologia Animal, Departamento de Medicina Veterinária, Centro de Ciências Agroveterinárias, Universidade do Estado de Santa Catarina, Av. Luiz de Camões 2090, Lages, SC 88520-000, Brazil. E-mail: aldo.gava@udesc.br

This study reported the epidemiological data and the clinical and pathological conditions of spontaneous poisoning by Ateleia glazioviana in sheep and goats in the West region of Santa Catarina. The small ruminants were located in a place where there was a large amount of young plants of A. glazioviana and showing signs of consumption. The stock of sheep was composed of 250 animals, of which 45 died. In the goat herd, there were 28 animals, and of these, 27 died, and one was sacrificed. The main clinical signs were weight loss, fatigue, slowwalk, and eventually submandibular and facial edema. Some animals were found dead, and others died suddenly after being moved. Abortions and the birth of weak lambs were also observed. In total, five sheep and one goat were necropsied. The main macroscopic lesions were associated to eccentric cardiac hypertrophy and moderate, multifocal white areas in the epicardium and myocardium. Two sheep showed marked edema in the subcutaneous tissue of the head and neck and it could be noted hydrothorax and hydroperitoneum and liver with a nutmeg-like appearance. Histological changes were relevant in the myocardium. They consisted of fibrosis and myofiber necrosis associated with macrophage infiltrate, multifocal, low and marked swelling of cardiomyocytes with loss of fibrillarystriae, and increased nuclear volume. In two sheep, there was still congenital hepatic, as well as marked centrilobular and diffuse areas.
\end{abstract}

INDEX TERMS: Toxic plants, Ateleia glazioviana, sheep, goats, heart failure.

\begin{abstract}
RESUMO.- [Intoxicação espontânea por Ateleia glazioviana (Leg. papilionoideae) em ovinos e caprinos no Oeste de Santa Catarina.] Descrevem-se dados epidemiológicos, sinais clínicos e lesões da intoxicação espontânea por Ateleia glazioviana em ovinos e caprinos no Oeste de Santa Catarina. Os ovinos e caprinos se encontravam em um local que havia grande quantidade de A. glazioviana jovem e com sinais de consumo. 0 plantel de ovinos era composto por 250 animais, dos quais 45 morreram. No rebanho caprino haviam 28 animais e destes, 27 morreram e um foi sacrificado. Os principais sinais
\end{abstract}

\footnotetext{
${ }^{1}$ Received on September 28, 2020.

Accepted for publication on October 21, 2020.

${ }^{2}$ Laboratório de Patologia Animal, Departamento de Medicina Veterinária, Centro de Ciências Agroveterinárias (CAV), Universidade do Estado de Santa Catarina (UDESC), Avenida Luiz de Camões 2090, Bairro Conta Dinheiro, Lages, SC 88520-000, Brazil. *Corresponding author: aldo.gava@udesc.br

${ }^{3}$ Veterinarian, Chapecó, SC, Brazil.

${ }^{4}$ Veterinarian, Xanxerê, SC, Brazil.
}

clínicos se caracterizaram por perda de peso, cansaço, caminhar lento e eventualmente edema submandibular e facial. Alguns foram encontrados mortos e outros morreram subitamente após serem movimentados. Abortos e nascimento de cordeiros fracos também foi observado. No total, cinco ovinos e um caprino foram necropsiados. As principais lesões macroscópicas foram hipertrofia excêntrica do coração e áreas brancas multifocais, moderadas, no epicárdio e miocárdio. Dois ovinos apresentaram edema acentuado no tecido subcutâneo da cabeça e pescoço, bem como hidrotórax, hidroperitôneo e fígado com aspecto de noz-moscada. As alterações histológicas foram relevantes no miocárdio e consistiram de áreas de fibrose e necrose de miofibras associada à infiltrado de macrófagos, multifocal, leve, além de tumefação acentuada de cardiomiócitos com perda das estrias fibrilares e aumento do volume nuclear. Em dois ovinos, havia ainda, congestão hepática, centrolobular, difusa.

TERMOS DE INDEXAÇÃO: Plantas tóxicas, Ateleia glazioviana, ovinos, caprinos, insuficiência cardíaca. 


\section{INTRODUCTION}

The species Ateleia glazioviana is a tree of the Fabaceae family (Papilionoideae) found in the Northwest of Rio Grande do Sul and in the West region of Santa Catarina (Lorenzi 1992). The plant is popularly known as "timbó", "Maria preta”, "cinamomo bravo" or "amargo" (Gava et al. 2001).

Spontaneous poisoning by A. glazioviana has been described in cattle. It has been associated with spongy degeneration of the white matter of the brain and acute and chronic changes in the myocardium, abortions, and including birth of weak animals likely to die in the neonatal period (Gava \& Barros 2001). Nervous clinical signs caused by plant poisoning, such as lethargy, blindness, incoordination, and abortions, have been experimentally confirmed (Gava 1993, Stolf et al. 1994, Gava et al. 2001, García y Santos et al. 2004). However, clinical signs associated with sudden death and/or engorgement of the jugular and edema in the pectoral region have not been experimentally confirmed, although the plant administration has induced cardiac lesions similar to those of spontaneous disease (Gava et al. 2001).

In sheep, poisoning by $A$. glazioviana was reproduced experimentally and resulted in cardiac, nervous, and reproductive changes similar to those observed in cattle (Stigger et al. 2001, Raffi et al. 2004, 2006).

The present study aimed to describe epidemiological, clinical, and pathological aspects of two outbreaks of spontaneous poisoning by A. glazioviana, one related to sheep and the others to goats.

\section{MATERIALS AND METHODS}

A survey of epidemiological data and clinical signs of a disease that affected sheep and goats was carried out in Chapecó and Bom Jesus, in the West region of Santa Catarina, where five sheep and one goat were necropsied, respectively. Fragments of liver, kidney, heart, lung, spleen, lymph nodes, central nervous system, rumen, reticulum, omasum, abomasum, intestine, and skeletal muscle were collected. The fragments were fixed in $10 \%$ formalin and routinely processed for histological evaluation at the "Laboratório de Patologia Veterinária" (LABOPAVE) of "Universidade Federal de Santa Catarina" (UFSC).

\section{RESULTS}

Clinical signs characterized by weight loss, tiredness, slowwalk, submandibular and facial edema were observed in two herds (one in sheep and the other in goats) in the West region of Santa Catarina. Most animals were found dead and/ or died suddenly after being moved. Regarding the Property 1 , there were 250 sheep of the Texel breed, aged from 1 to 8 years old, the vast majority of which were composed of sheep. Forty females and five males died. There was information on abortions and the birth of weak lambs that died in the first days after birth. On Property 2, there were 28 mixed breed goats, aged from 2 to 6 years old, 27 females and one male. Of these, 27 died naturally, and the last was sacrificed for a necropsy. In both properties, it was observed that where the sheep and goats had been raised in these areas, there were many young plants of Ateleia glazioviana showing signs of consumption.

With respect to the necropsy of the five sheep (four females and one male) and one goat, the macroscopic lesions were marked on the cardiac muscle and consisted of white areas (Fig.1) with rigid consistency and marked dilation of the ventricular chambers. Two sheep presented marked edema in the subcutaneous tissue of the head, neck, hepatic hydrothorax, hydroperitoneum, and liver showing the classical aspect of nutmeg liver. In all necropsied sheep and goats, the main microscopic lesions were observed in the heart. They consisted of areas of myofiber necrosis and collagen deposition with a proliferation of fibrous tissue (Fig.2 and 3),

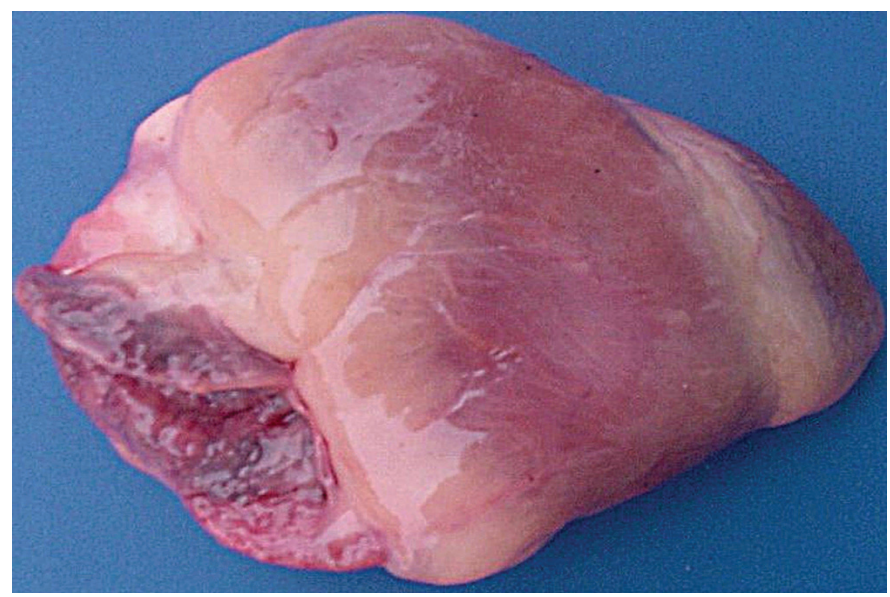

Fig.1. Poisoning by Ateleia glazioviana. Sheep. Heart. Pale areas in the myocardium.

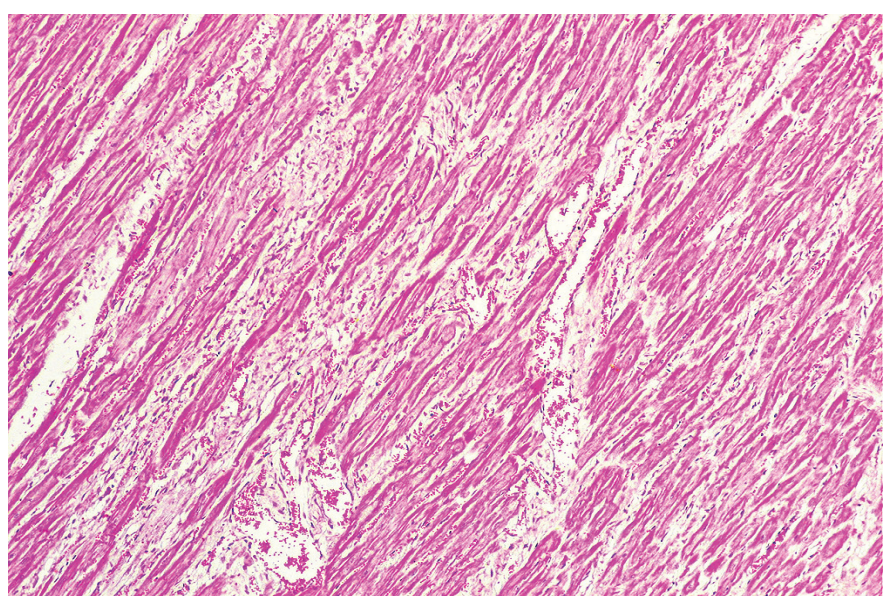

Fig.2. Poisoning by Ateleia glazioviana in goats. Cardiac muscle: proliferation of fibrous tissue, diffuse. HE, obj.10x.

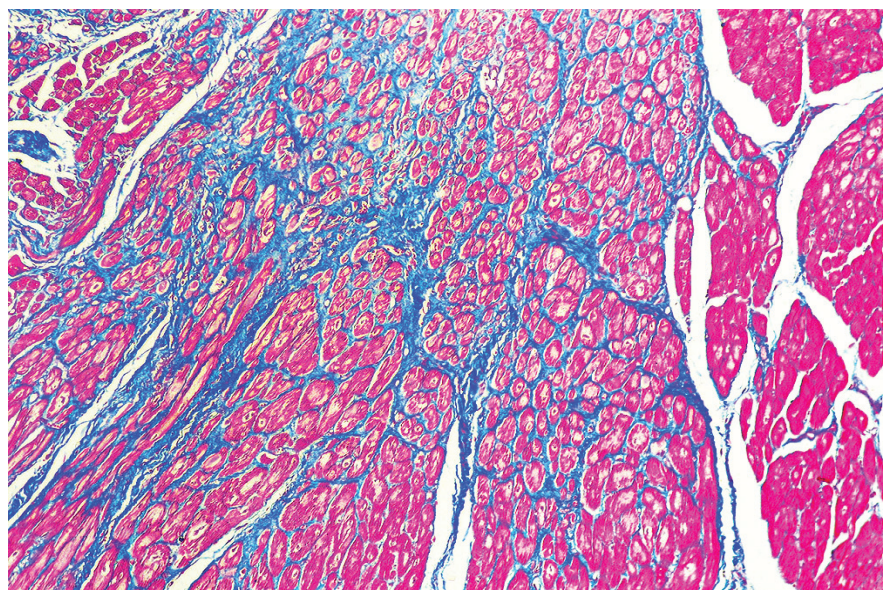

Fig.3. Poisoning by Ateleia glazioviana in sheep. Cardiac muscle: fibrosis. Masson's trichrome, obj.10x. 
associated with light macrophage infiltrate, in addition to marked swelling of cardiomyocytes with loss of fibrillary striae and increased nuclear volume. In the two sheep that had a nutmeg liver, it could be observed a moderate, diffuse center lobular congestion, and due to the histochemical staining of Mason's Trichrome, no fibrosis was observed.

\section{DISCUSSION}

Diagnosis of spontaneous poisoning by Ateleia glazioviana in sheep and goats was based on epidemiological data, clinical signs, and gross and microscopic lesions. The abortions, the presence of a large number of young plants (born from seed) of $A$. glazioviana where sheep and goats were found, the observation of the plant consumed, the histories of sudden deaths and macroscopic and microscopic lesions were similar to those reported in plant poisoning in cattle (Gava et al. 2001, Gava \& Barros 2001).

The clinical signs, gross and microscopic lesions of sheep and goats in the present study were associated with chronic heart failure. In the histological examination, the lesions were marked in the cardiac muscle, evidenced by areas of fibrosis and necrosis of myofibers. This clinical and pathological conditions were similar to that described in spontaneous and experimental poisoning by A. glazioviana in cattle (Gava et al. 2001, Gava \& Barros 2001) and experimental reproductions in sheep (Stigger et al. 2001, Leite et al. 2002, Raffi et al. 2004, 2006).

Stigger et al. (2001) have described the spongy degeneration in four of the seven sheep used experimentally. Spongiform degeneration in the central nervous system has also been described in cattle that showed lethargy and blindness (Gava et al. 2001). No changes in the central nervous system were observed in the sheep and goats of the present study. It is worth noting that these animals did not show lethargy and blindness before the necropsy had been started. Thus, it can be said that the spongy degeneration caused by A. glazioviana in cattle, sheep, and goats only occurs during the initial stage of ingestion of the plant when they show lethargic signs and blindness.

In the early 90 s, experiments on pregnant rats using some compounds from $A$. glazioviana leaves had already proven their abortive effect and potential to cause fetal resorption (Langeloh et al. 1992, Marona et al. 1992). However, in experimental breeding using rats, mice, rabbits, and guinea pigs, it was demonstrated that these animals were not susceptible to the cardiotoxic and abortive effect of plants (Leite et al.2002). The abortions that occurred in the present report were similar to the descriptions of spontaneous and experimental poisoning of the disease in cattle (Gava 1993, Stolf et al. 1994, Gava et al. 2001, Gava \& Barros 2001, García y Santos et al. 2004), as well as experimental reproduction in sheep (Stigger et al. 2001).

The poisoning by A. glazioviana must be distinguished from poisoning by other plants that affect the heart function, and these are divided into two groups. Among the plants that cause sudden death and evolution of severe and acute symptoms in sheep and goats, there are spontaneous and/or experimental poisonings by Palicourea spp. (Tokarnia etal.1986, 1991, Passos et al. 1990, Blanco et al. 2004), Pseudocalymma elegans (Tokarnia et al. 1993, Consorte et al.1994, Helayel et al. 2011), and poisoning by Amorimia spp. (Bandarra et al. 2005, Vasconcelos et al. 2008, Schons et al. 2011, Soares et al. 2011, Becker et al. 2013). In general, animals poisoned by these plants do not manifest previous clinical changes or macroscopic lesions, which differs from poisoning by $A$. glazioviana Outbreaks of poisoning by ionophore antibiotics have been described in sheep (Bastianello et al. 1995, Wouters et al. 1997, França et al. 2009, Rissi \& Barros 2010) and cause a clinical and pathological conditions similar to A. glazioviana poisoning. However, sheep poisoned by ionophores have some distinct signs and injuries, such as diarrhea and signs of muscle weakness. In addition to cardiac injuries, there may be injuries to skeletal muscles. Selenium deficiency has also been described in sheep and goats and causes lesions similar to poisoning by A. glazioviana (Loretti et al. 2001, Amorim et al. 2005), but can be differentiated due to injuries in the skeletal muscles, which is observed in poisonous plant, such as A. glazioviana.

In the group of plants that cause cardiac lesions from subacute to chronic evolution, it could be described experimental reproduction by Tetrapterys spp. in sheep and goats (Melo et al. 2001, Riet-correa et al. 2005, Carvalho et al. 2006, Almeida 2006, Almeida et al. 2008, Cardinal et al. 2010). The differential diagnosis between poisoning by these plants is based mainly on the plant disease epidemiology and their presence in the region.

There seems to be no treatment descriptions for A.glazioviana poisoning. Prophylactic measures can minimize economic losses, such as keeping animals from eating these plants and controlling them, as already described by Gava et al. (2001).

\section{CONCLUSION}

The species Ateleia glazioviana in the early and seed-born stages can be ingested by sheep and goats and produce miscarriages and severe cardiac injuries, leading to the manifestation of congestive heart failure and/or sudden death.

Conflict of interest statement.- The authors have no competing interests.

\section{REFERENCES}

Almeida M.B. 2006. Avaliação das lesões cardíacas e encefálicas induzidas pelas intoxicações por Ateleia glazioviana e Tetrapterys multiglandulosa em ovinos. Master's Thesis in Veterinary, Laboratório Regional de Diagnóstico, Faculdade de Veterinária, Universidade Federal de Pelotas, Pelotas. 56p.

Almeida M.B., Priebe A.P.S., Riet-Correa B., Riet-Correa G., Fiss L., Raffi M.B. \& Schild A.L. 2008. Evolução e reversibilidade das lesões neurológicas e cardíacas em ovinos intoxicados experimentalmente por Ateleia glazioviana e Tetrapterys multiglandulosa. Pesq. Vet. Bras. 28(3):129-134. <https://dx.doi.org/10.1590/S0100-736X2008000300001>

Amorim S.L., Oliveira A.C.P., Riet-Correa F., Simões S.V.D., Medeiros R.M.T \& Clementino I.J. 2005. Distrofia muscular nutricional em ovinos na Paraíba. Pesq. Vet. Bras. 25(2):120-124. <https://dx.doi.org/10.1590/ S0100-736X2005000200010>

Bandarra P.M., Colodel E.M., Raymundo D.L., Pedroso P.M.O., Borba M.G. \& Driemeier D. 2005. Intoxicações em ruminantes por Mascagnia sp. no Rio Grande do Sul diagnosticados no setor de Patologia Veterinária, Universidade Federal do Rio Grande do Sul, Porto Alegre. Ciências Agrárias, p.270.

Bastianello S.S., Fourie N., Prozesky L., Nel P.W. \& Kellerman T.S. 1995. Cardiomiopathy of ruminants induced by litter of poultry fed on rations containing Theionophore antibiotic, maduromicin. II. Macropathology and histopathology. Onderstepoort J. Vet. Res. 65(1):5-18. <PMid:8539035>

Becker M., Caldeira F.H.B., Carneiro F.M., Oliveira L.P., Tokarnia C.H., RietCorrea F., Lee S.T. \& Colodel E.M. 2013. Importância da intoxicação por Amorimia pubiflora (Malpighiaceae) em bovinos em Mato Grosso: reprodução 
experimental da intoxicação em ovinos e bovinos. Pesq. Vet. Bras. 33(9):10491056. <https://dx.doi.org/10.1590/S0100-736X2013000900001>

Blanco B.S., Haraguchi M., Silva J.A. \& Górniak S.L. 2004. Intoxicação natural de caprinos e ovinos por palicourea marcgraviist hil. (rubiaceae). Caatinga, Mossoró, 17(1):52-56.

Cardinal S.G., Aniz A.C., Santos B.S., Carvalho N.M. \& Lemos R.A.A. 2010. Lesões perinatais em cordeiros induzidas pela administração de Tetrapteris multiglandulosa (Malpighiaceae) a ovelhas em diferentes estágios de gestação. Pesq. Vet. Bras. 30(1):73-78. <https://dx.doi.org/10.1590/ S0100-736X2010000100012>

Carvalho N.M., Alonso L.A., Cunha T.G., Ravedutti J., Barros C.S.I. \& Lemos R.A.A. 2006. Intoxicação de bovinos por Tetrapterys multiglandulosa (Malpighiaceae) em Mato Grosso do Sul. Pesq. Vet. Bras. 26(3):139-146. <https://dx.doi.org/10.1590/S0100-736X2006000300002>

Consorte L.B., Peixoto P.V. \& Tokarnia C.H. 1994. Intoxicação experimental por Pseudocalymma elegans (Bignoniaceae) em ovinos. Pesq. Vet. Bras. 14(4):123-133.

França T.N., Nogueira V.A., Yamasaki E.M., Caldas S.A., Tokarnia C.H. \& Peixoto P.V. 2009. Intoxicação acidental por monensina em ovinos no Estado do Rio de Janeiro. Pesq. Vet. Bras. 29(9):742-746. <https://dx.doi.org/10.1590/ S0100-736X2009000900011>

García y Santos M. del C., Schild A.L., Barros S.S., Riet-Correa F., Elias F. \& Ramos A.T. 2004. Lesões perinatais em bovinos na intoxicação experimental por Ateleia glazioviana (Leg.Papilionoideae). Pesq. Vet. Bras. 24(4):178-184. <https://dx.doi.org/10.1590/S0100-736X2004000400002>

Gava A. \& Barros C.S.L. 2001. Field observations on the Ateleia glazioviana poisoning in cattle in southern Brazil. Vet. Human Toxicol. (43):7-41. <PMid:11205077>

Gava A. 1993. Intoxicação por Ateleia glazioviana, p.222-239. In: Riet-Correa F., Méndez M.C. \& Schild A.L. (Eds), Intoxicações por Plantas e Micotoxicoses em Animais Domésticos. Hemisfério Sul, Pelotas.

Gava A., Barros C.S.L., Pilati C., Barros S.S. \& Mori A.M. 2001. Intoxicação por Ateleia Glazioviana (Leg. Papilionoideae) em bovinos. Pesq. Vet. Bras. 21(2):49-59. <https://dx.doi.org/10.1590/S0100-736X2001000200003>

Helayel M.A., Caldas S.A., Peixoto T.C., França T.N., Tokarnia C.H., Dobereiner J., Nogueira V.A. \& Peixoto P.V. 2011. 0 antagonismo com acetamida em experimentos com ovinos, caprinos e coelhos indica monofluoroacetato como princípio tóxico de Pseudocalymma elegans Bignoniaceae. Pesq. Vet. Bras. 31(10):867-874. <https://dx.doi.org/10.1590/S0100-736X2011001000006>

Langeloh A., Leguizanón F. \& Dalsenter P. 1992. Potencial abortivo e infertilizante de plantas brasileiras contaminantes ocasionais de pastagens de bovinos e outros herbívoros de interesse econômico. Pesq. Vet. Bras. 12(1/2):11-18.

Leite L.G., Riet-Correa F., Medeiros R.M.T., Piacenti A., Aragão M. \& Schons S.V. 2002. Susceptibility of laboratory animals to the toxic effects of Ateleia glazioviana (Leg. Papilionoideae). Pesq. Vet. Bras. 22(2):73-78. <https://dx.doi.org/10.1590/S0100-736X2002000200007>

Lorenzi H. 1992. Árvores brasileiras: manual de identificação e cultivo de plantas arbóreas do Brasil. Vol.1. Plantarum, Nova Odessa, p.194.

Loretti A.P., Driemeier D., Traverso S.D. \& Seitz A.L. 2001. Miopatia nutricional em caprinos no Rio Grande do Sul. Anais 10 Encontro Nacional de Patologia Veterinária, Pirassununga, SP, p.36.

Marona H.R.N., Langeloh A. \& Schenkel E.P. 1992. Atividade abortiva de Ateleia glazioviana (Leg. Papilionoideae) em ratas. Pesq. Vet. Bras. 12 (3/4):81-83.
Melo M.M., Vasconcelos A.C., Dantas G.C., Serakides R. \& Alzamora Filho F. 2001. Experimental intoxication of pregnant goats with Tetrapterys multiglandulosa A. Juss. (Malpighiaceae). Arq. Bras. Med. Vet. Zootec. 53(1):58-65. <https://dx.doi.org/10.1590/S0102-09352001000100009>

Passos D.A., Silva F.M. \& Cavalcante M.I. 1990. Intoxicação experimental em caprinos (Capra hircus) por Palicourea aeneofusca (M. Arg.) Standl. (Rubiaceae). Cad. ômega Univ. Fed. Rural PE. Sér. Vet., Recife, (4):15-20.

Raffi M.B., Barros R.R., Bragança J.F., Rech R.R., Oliveira F.N. \& Barros C.S.L. 2004. The pathogenesis of reproductive failure induced in sheep by the ingestion of Ateleia glazioviana. Vet. Human Toxicol. 46(5):233-238. <PMid:15487641>

Raffi M.B., Rech R.R., Sallis E.S.V, Rodrigues A. \& Barros C.S.L. 2006. Miocardiopatia Crônica e degeneração esponjosa do encéfalo em ovinos intoxicados experimentalmente por Ateleia glazioviana. Ciência Rural 36(6):1860-1866. <https://dx.doi.org/10.1590/S0103-84782006000600030>

Riet-Correa G., Terra F.F., Schild A.L., Riet-Correa F. \& Barros S.S. 2005. Intoxicação experimental por Tetrapterys multiglandulosa (Malpighiaceae) em ovinos. Pesq. Vet. Bras. 25(2):91-96. <https://dx.doi.org/10.1590/ S0100-736X2005000200005>

Rissi D.R. \& Barros C.S.L. 2010. Intoxicação espontânea por antibióticos ionóforos em ovinos no Rio Grande do Sul. Pesq. Vet. Bras. 30(3):219-221. <https://dx.doi.org/10.1590/S0100-736X2010000300005>

Schons S.V., de Mello T.L., Riet-Correa F. \& Schild A.L. 2011. Poisoning by Amorimia (Mascagnia) septium in sheep in northern Brazil. Toxicon 57(5):781-786. <https://dx.doi.org/10.1016/j.toxicon.2011.02.012> <PMid:21333667>

Soares M.P., Pavarini S.P., Adrien M.L., Quevedo P.S., Schild A.L., Peixoto P.V., Cruz C.E.F. \& Driemeier D. 2011. Amorimia exotropica poisoning as a presumptive cause of myocardial fibrosis in cattle. J. Vet. Diagn. Invest. 23(6):1226-1229. <https://dx.doi.org/10.1177/1040638711425586> <PMid:22362807>

Stigger A.L., Barros C.S.L., Langohr I.M. \& Barros S.S. 2001. Intoxicação experimental por Ateleia glazioviana (Leg. Papillionoidea) em ovinos. Pesq. Vet. Bras. 21(3):98-108.

Stolf L., Gava A., Varaschin M.S., Neves D.S., Mondadori A.J. \& Scolari L.S. 1994. Aborto em bovinos causado pela ingestão de Ateleia glazioviana (Leg. Papilionoideae). Pesq. Vet. Bras. 14(1):15-18.

Tokarnia C.H., Peixoto P.V. \& Döbereiner J. 1986. Intoxicação experimental por Palicourea marcgravi (Rubiaceae) em ovinos. Pesq. Vet. Bras. 6(4):121-131.

Tokarnia C.H., Peixoto P.V. \& Döbereiner J. 1991. Intoxicação experimental por Palicourea marcgravi (Rubiaceae) em caprinos. Pesq. Vet. Bras. 11(3/4):65-70.

Tokarnia C.H., Peixoto P.V. \& Döbereiner J. 1993. Intoxicação experimental por Pseudocalymma elegans (Bignoniaceae) em caprinos. Pesq. Vet. Bras. 13(1/2):35-39.

Vasconcelos J.S., Riet-Correa F., Medeiros R.M.T., Dantas A.F.M., Galiza G.J.N., Oliveira D.M. \& Pessoa A.F.A. 2008. Intoxicação por Mascagnia rígida (Malpighiaceae) em ovinos e caprinos. Pesq. Vet. Bras. 28(10):521-526. <https://dx.doi.org/10.1590/S0100-736X2008001000013>

Wouters F., Wouters A.T.B. \& Barros C.S.L. 1997. Intoxicação experimental por narasina em ovinos. Pesq. Vet. Bras. 17(3/4):89-95. <https://dx.doi. org/10.1590/S0100-736X1997000300001> 